\title{
Migrants and Other Others in 2020 by Javier Moreno
}

Carolina Leon Vegas

Dalarna University

\section{Introduction}

The U.S.-Mexican border es una herida abierta where the Third World grates against the first and bleeds. And before a scab forms it hemorrhages again, the lifeblood of two worlds merging to form a third country - a border culture. (Gloria Anzaldúa, I987, p. 3 )

Borders can exist on many different levels in a text: between the textual and the extratextual, between the levels of the narration, and between the reader and the text. In this article, I will approach the notion of the border as a gateway into the study of the relation between otherness, space and the body. There is an invisible border between $\mathrm{Me}$ and the Other. It is defined by empty space but also by the visual and physical aspects of the body that differentiate them, such as socio-economic status, ethnicity or gender. At a more tangible level, the body is the border that constitutes, surrounds and isolates the individual, thus setting the grounds for otherness. In her quote above, Anzaldúa illustrates the connection between liminal space ${ }^{\mathrm{I}}$ and the body through a metaphor which builds upon corporal elements humanizing an otherwise geographic element, the border, and stresses the suffering contained in the space she portrays: the borderland, a border zone. Anzaldúa's metaphor serves to illustrate the connections

I The notion of liminality, whose origin is to be found in the anthropological theories of van Gennep (The Rites of Passage), is used here in its sense of a place in the border, a place of transit between different areas.

How to cite this book chapter:

Vegas, C. L. 202 I. Migrants and Other Others in 2020 by Javier Moreno. In: Jonsson, H., Berg, L., Edfeldt, C. and Jansson, B. G. (eds.) Narratives Crossing Borders: The Dynamics of Cultural Interaction. Pp. $5 \mathrm{I}-74$. Stockholm: Stockholm University Press. DOI: https://doi.org/Io.I6993/bbj.c. License: CC-BY 4.0 
between two different and yet parallel spatial notions: the dichotomy center-periphery on the one hand, and in-betweenness, "the border culture", on the other hand. The border, apart from its thin lineal function as a mere separator of two areas, is itself a space: a space in between, a limbo, a hybrid location.

In this study of otherness, space and the body, I will explore the novel 2020, written by the Spanish poet and novelist Javier Moreno and published in 2013. The text offers a dystopian image of Madrid in the year 2020 after the financial crisis and presents at its center the figure of Bruno Gowan, a Scottish business executive who is missing from home and his job and for whom a search is now underway. The novel is built around short chapters that follow different characters belonging to different genders, races, nationalities, ages and sociocultural backgrounds. These characters include Josefina, Gowan's daughter, an attractive young anorexic who is obsessed with her body and enjoys acquiring luxury items; Nabil, a well-educated, young Saharawi man, who lives in an abandoned plane because he cannot find a job; and Jorge, an obese man with Asperger's syndrome who works in a Chinese bazaar and shares the plane with Nabil. The father of Josefina, the tutor of Nabil and the victim of Jorge, Gowan is the link between all these characters.

As other studies have pointed out, 2020 is a powerful representation of a country in crisis, as well as its causes and consequences ${ }^{2}$. Michelle Murray calls it a "formidable novel of socioeconomic decline" and argues that space plays a "vital dimension" in this portrayal of crisis (Murray, 20I6, p. 73). While I agree, my aim is to look at other spatial aspects of 2020 that I believe to be just as central. The novel's futuristic gaze on an urban society in decay is built by and on the portrait of the oddness and uniqueness of the characters that form the core of the text. These characters are all peculiar in a quite disproportionate way, with Bruno Gowan, as the utmost representation of deviation, situated at the epicenter of the narration.

2 The novel of the crisis (novela de la crisis), novels that portray the socioeconomic aspects of the financial crisis of 2008 , has been studied by a series of critics and journalists: Javier Rodríguez Marcos (2013), Julio Vélez Sainz (20I4), David Becerra (20I 5), Valdivia (20I6), and Murray (20I6). 


\section{Center-Periphery and the Portrait of the Migrant}

The Irish writer Lisa McInerney has pointed out that literature in English is mostly written by and for the middle classes and frequently portrays well-educated characters with different personal afflictions (Marín, 20I6). The working classes are largely absent and, as Beatriz Celaya-Carrillo points out, the representation of the migrant is also scarce. The same holds true in Spanish literature (20II, p. 344). In many contemporary Spanish texts, even those concerned with recent contemporary crises and its effects on people, migrants do not figure. Instead, the action reverberates around middle-class characters who are losing ground. Migrants, the ones on whom the crisis has taken the hardest toll, often have a secondary, merely decorative function in these texts, portraying diminutive and anecdotal figures such as the Asian maid, the Latin prostitute, the Chinese bazaar worker or the Romanian pickpocket ${ }^{3}$. Moreno's 2020 includes similar stereotypical references to minor characters such as Josefina's Philippino house cleaner or the Thai internet prostitute, characters who are mentioned briefly and seem to have only an ornamental function. However, the novel goes beyond this and places at the center of its narration two characters with roots outside Spain: Gowan and Nabil. Far from the archetypal images commonly present in current-day narratives on crisis, these two figures impersonate hybrid and peculiar individuals. Gowan is a second-generation Scottish migrant who, far from representing poverty or failure, is a rich, influential businessman who has now fled this life to embark

3 This observation, as well as others in this article, is based on my reading of a number of books portraying the crisis: Panfleto para seguir viviendo by Fernando Díaz (20I4), Los ciervos llegan sin avisar by Berna González Harbour (2015), El comité de la noche by Belén Gopegui (2014), Los besos en el pan by Almudena Grandes (2015), Democracia by Pablo Gutiérrez (20I2), La trabajadora by Elvira Navarro (20I4), Vente a casa by Jordi Nopca (2015), Ajuste de cuentas by Benjamín Prado (2013), Compro oro (2013) and La habitación oscura (2013) by Isaac Rosa. A text that breaks this norm of absence or limitation in the portrait of the migrant is En la orilla (2013) by Rafael Chirbes, a masterly example of how a text can transmit the strangeness, fear and vulnerability of the migrant through a character's own perspective. Chirbes's realistic, introspective style is different from Javier Moreno's more fragmentary and futuristic prose, but they share the inclusion of migrant characters at the heart of their novels. 
on a quest for social change. Nabil, a homeless migrant with a university education, has become part of Gowan's quest. Dressed in his presents of an Armani suit, Vuitton shoes and a Breitling watch, Nabil acts as Gowan's submissive, and at times resentful, personal assistant.

Pablo Valdivia (2016, p. 34) argues for the existence of a new literature of the disinherited in Spain, a literature about poverty and deprivation. Valdivia's concept, the origin of which can be found in the work of the historian Henry Kamen ${ }^{4}$, can be associated with McClung's notion of the betrayed arcadia "whose good days are hopelessly lost" (I988, p. 34) and of the promise of a future life that never comes. This sense of want and failure is a recurring topic in the portrayal of Nabil: "He had never possessed anything and, yet, he fights hard to find something that lays hidden somewhere, waiting for him" (p. I83)5. However, as this quote suggests, Nabil is not so much disinherited as uninherited, and that is a part of his otherness, of his strangeness. A recurring feature in the crisis literature that I have read is the representation of a loss, of a removal of something that had been acquired or was supposed to come with time, through the themes of unemployment, eviction and precariousness. In the case of Nabil, however, rather than the loss (of something promised or awaited), there is absence and rather than a deprivation, there is a privation. Despite his fight for an education and for a job, Nabil is excluded and transmits his outcast position in these words: "I am an outcast. I am less than a proletarian. A descendant from men and women who made the desert their home" (p. 20 $)^{6}$. Through this acknowledgment of his north African origins, Nabil associates his feeling of exclusion to a landscape, the desert, and at the same

${ }^{4}$ In his book The Disinherited; Exile and the Making of Spanish Culture, Henry Kamen uses the notion of the disinherited to talk about different groups of exiled people through Spanish history. Valdivia's use of the term is different as he relates it to the loss and precariousness associated with a financial crisis.

5 "Él no había poseído nunca nada y, sin embargo, lucha denodadamente por encontrar algo que yacía escondido en algún lugar, esperándolo” (p. I 83). This, and all subsequent translations into English in this article, are mine.

6 "Soy un descastado. Soy menos que un proletario. Un descendiente de hombres y mujeres que hicieron del desierto su hogar” (p. 20). 
time to a nationality and ethnicity that this element implies. This character is a border crosser on many levels. Geographically, he has moved from Africa to Europe, from Morocco to Spain, and from the desert to the city. At a cultural level, he has made the journey from illiteracy to university educated. However, in socioeconomic terms, the trajectory is less linear and seems to reverse and turn back, as after years of fighting, studying and looking for a job, he finds himself in homelessness and total exclusion. As Nabil puts it, "The present on the other hand is hardship, helplessness" (p. 2I $)^{7}$. When these thoughts are articulated, Nabil is living in an abandoned plane together with other homeless people. The airplane - normally a symbol of luxury, movement, and a search for the exotic - is in 2020 turned into a static container of failed destinies. It is an undoubtedly powerful image of a rusty, defeated Titanic (or titan), broken and brought down.

Described as "the angel of revolution" (p. 97) ${ }^{8}$, Nabil has been chosen by Gowan to help him in his mission, a revolution which, throughout the novel, remains unclear in terms of its objectives or methods. Nabil's position, falling asleep in the cockpit of this abandoned plane, can be seen, in the context of this revolution, as the image of a co-pilot bound to fail and fall, or even a co-pilot already fallen. Murray $(2016$, p. 85$)$ connects this image of the plane to the failure of the economic system ${ }^{9}$. She points out the liminality of this space, referring to periphery and to Augé's notion of non-place ${ }^{\text {Io }}$ when she says "The characters reside in a socioeconomic oblivion situated on the periphery of the frightful, futuristic capital” (Murray, 20I6, p. 85). Although this does not apply to all characters (Josefina, for instance, does not live in this

7 "El presente en cambio es la intemperie, el desamparo" (p. 2 I).

8 “El ángel de la revolución” (p. 97).

9 Murray writes that the "airplane imagery could represent a crash, an unexpected real and physical tragedy with atrocious consequences" (Murray, 20I6, p. 85) and links it to the "senseless nature of capital as it creates scenarios akin to those of a plane crash through market speculation" (Murray, 2016, p. 85 ).

to The notion of non-place was developed by Marc Augé in his book Nonplaces: introduction to an anthropology of supermodernity. Non-places are places of transit associated with consumerism and supermodernity, another notion by Augé. Examples of non-places are airports, shopping centers and hotels. 
liminality), the notion of periphery is central to understanding Nabil. In a colonial sense, this Saharawi character clearly comes from the periphery, from the sterility and nothingness of the desert. Once in Madrid, the capital, the center, Nabil spends his childhood in Villaverde, an especially deprived area on the outskirts of Madrid. At the time of the action in the novel, Nabil has moved from one peripheral location to another, from Villaverde to the airport: a space beyond the city, a space between nations, and, as Mora points out, a kind of limbo (2014, p. I 5-I 7). Nabil's steps seem to start and end in similarly empty places, from the emptiness of the desert he comes from to the featureless expanse of the airport or, as he puts it, "the plateau, that geographic tribute to nothingness" (p. 38$)^{\mathrm{II}}$. The blurriness of this spatial limbo seems to extend to Nabil's conception of himself when at one point he wakes up with the thought: "I am a nebula" (p. 37) $)^{12}$ In the character of Nabil there is a sense of confusion and contradiction. The space he inhabits, a plane that houses homeless people, contrasts with his awareness of his visual appearance:

A homeless Saharawi wearing an Armani suit is suspicious enough. The airstrip is frozen. I expand my arms searching for balance. Vuitton shoes were not designed to walk on ice. I imagine one of the homeless people looking through the window, rubbing his eyes at the unreality of the scene; a man wearing an executive suit slides towards an abandoned plane. (p. I9) ${ }^{\text {13 }}$

Nabil's sense of otherness, expressed in his feeling of being seen as suspect, is conveyed in terms of spatiality. His spatial position, at the airport's abandoned landing area, together with his attire, is what creates an incongruence and a feeling of being strange.

Nabil's sense of otherness is linked to the imagined gaze of another person and is connected to the sense of suspicion that

\footnotetext{
ir "la meseta castellana, ese homenaje geográfico a la nada” (p. 38 ).

I2 “Soy una nebulosa” (p. 37).

${ }_{3}$ "Bastante sospechoso resulta el hecho de que un saharaui que no tiene dónde caerse muerto vista un traje de Armani. La pista está helada. Extiendo los brazos en busca de equilibrio. Los Vuitton no fueron diseñados para caminar sobre hielo. Imagino a uno de los sin techo asomado a la ventanilla, frotándose los ojos ante la irrealidad de la escena: un hombre vestido con traje de ejecutivo se desliza hacia un avión abandonado" (p. I9).
} 
in the text remains a mental construction because it appears as a self-perception. At the same time, the strangeness has a strong spatial (and ethnic) dimension because it is the fact that Nabil finds himself in a peripheral space occupied by marginalized people that makes his appearance "unreal". Nabil and the plane share the rich-poor duality; both are an image of the coexistence of luxury and ruin and both have been deprived of their supposed social function.

Bruno Gowan partially shares Nabil's outcast position. He too is hidden and has lost the privileged life he used to have as a successful and married business executive living in a luxury house. Bruno Gowan is the main Other in the novel, but his otherness is not built so much on a sense of deprivation as on his portrayal as superior and unique. Gowan is described throughout the novel by different characters as being a special and outstanding figure. For Josefina he is "the only genius I know" (p. I65) I4. For Lázaro, the person in charge of finding him, the dossier he has been given about Gowan reveals his outstanding performance at university and his multiple achievements as the youngest director of a multinational telecommunications company, a professional tennis player and a critically-acclaimed visual artist, with paintings that now hang in prestigious art galleries. Gowan's self-perception is also one of being exceptional or singular: "I have grown. I have flourished. I am mortally beautiful. ... My kingdom, Nabil, is not from this world" (p. 95). ${ }^{15}$

The interaction of these two characters, Bruno Gowan and Nabil, is asymmetric and can be seen as representing the wider relationship between center-periphery, Africa-Europe, rich-deprived. The imbalance of power between these two characters prevails throughout the text. Gowan, representing the center, has a paternalistic and dominant attitude towards Nabil, whose function seems to be that of a disciple. At the same time, Nabil also seems to operate as an assistant, a subaltern in the postcolonial sense of

\footnotetext{
${ }_{14}$ "el único genio que conozco" (p. I65).

is "He crecido. He florecido. Soy mortalmente bello... Mi reino, Nabil, no es de este mundo" (p. 95).
} 
the term ${ }^{16}$. Whereas this character seems to accept quite naturally his role, Gowan displays the contradictions, the love-hate feelings, inherent in his father figure role, which crystallize when he says "I love you so much, that I could spit at you" (p. 97 ${ }^{17}$. With his quest that nobody fully understands, Gowan is a quixotic figure. As Josefina, his daughter, puts it: "Many people made the mistake of trying to understand my father" (p. I66) ${ }^{18}$. However, far from Don Quixote's naiveté and kindness, Gowan's aims and methods seem to stem from more complex artistic and philosophical urges. And if Gowan shows quixotic features, Nabil has certain parallels with the figure of Sancho Panza, whose motives in his quest alongside Don Quixote were equally economic. Gowan's material gifts to Nabil (his Breitling watch, Armani suit and Vuitton shoes) echo Quixote's promise of an island where Sancho could be the Governor. Like Sancho, Nabil also seems to share a fascination with and submissiveness towards his patron, whom he perceives as unnaturally remarkable:

It is difficult to follow Gowan's steps. To detect his movements becomes an exercise in perceptive acuteness. He manages to make an instant last more than agreed. He dances an $8 / 8$ rhythm while the rest of the dancers move to a $2 / 4$. Like a rat in a world of sloths. If I tried to hit him I would not know where to throw my fist. (p. 46) ${ }^{\text {19 }}$

This quote is relevant as it reaffirms Gowan's singularity, which in other characters' speeches acquires divine tones, such as when

${ }^{16}$ There have been a number of different definitions of and discussions about the term subaltern, a notion that has been fruitfully developed by the Subaltern Studies Group and theorists such as Gayatri Spivak. It is not the aim of this text to add to the discussions on the notion of the subaltern. When used in this chapter, it will be associated with powerlessness, exclusion and subjugation.

${ }_{17}$ "Te amo tanto, que podría escupirte" (p. 97).

I8 "Muchas personas cometieron el error de intentar comprender a mi padre” (p. I66).

19 "Es complicado seguir los pasos de Gowan. Detectar sus movimientos se convierte en un ejercicio de agudeza perceptiva. Consigue hacer que el instante dure más de lo convenido. Baila un ocho por ocho mientras que el resto de los bailarines nos movemos siguiendo un dos por cuatro. Como una rata en un mundo de perezosos. Si intentara golpearlo no sabría dónde lanzar el puño" (p. 46). 
Lázaro describes Gowan as "an idol in front of whom one humbles oneself" ${ }^{\circ}$ (p. 54) or when Josefina says "my father did God's work" ${ }^{21}$ (p. I 66). However, the quote's final sentence suggests the violence and resentment that lies behind this adulation, suffocated but present in the center-periphery relationship. Nabil's submission coexists with a desire to hurt, a thought that also manifests itself later on in the book in a passage where Gowan puts into words the relationship between the two men:

I am reason disguised as barbarity. You are uncontrollable nature under the seductive appearance of culture. You have learnt my language, but you introduce error into it. You are not to blame. Your origin, your class gives you away... The cultivated slave loses contact with their peers and ends up, terrible paradox, confessing to their master. Only the master understands his worries, only the master values and acknowledges him. Still, you will never be like me, Nabil. I dictate and you copy my words. You use my language and fill it with blots. You know it, and that thought feeds your hatred and poisons you.

I [Nabil] look at the knife again. A faint impulse would be enough. It would be fair. (p. 206 $)^{22}$

In Gowan's discourse one can find some revealing contrapositions, such as nature-culture or slave-master, that reinforce the classic postcolonial duality of center-periphery present in his relationship with Nabil. Gowan's patronizing and arrogant words here seem to awaken in Nabil a murderous impulse to stab Gowan, but he eventually leaves the knife and goes back to his keyboard. Even if this could be seen as an apparent attempt at revolt, Gowan

20 "un ídolo ante el que uno se humilla" (p. 54).

2г "mi padre hacía el trabajo de Dios" (p. I 66).

22 "Yo soy la razón disfrazada de barbarie. Tú eres la naturaleza incontrolable bajo la seductora apariencia de la cultura. Has aprendido mi idioma, pero introduces en él el error. No eres culpable. Te delata tu origen, tu clase... El esclavo cultivado pierde el contacto con sus semejantes y acaba teniendo que confesarse, terrible paradoja, con su amo. Solo el amo comprende sus cuitas, solo el amo lo valora y lo reconoce. Aun así nunca podrás ser como yo, Nabil. Yo dicto y tú copias mis palabras. Usas mi registro y lo colmas de borrones. Lo sabes, y ese pensamiento alimenta tu odio y te envenena.

Miro de nuevo el puñal. Bastaría un leve impulso. Sería fácil. Sería justo.” (p. 206). 
seems to be the brains behind it. He has given the knife to Nabil, claiming that it was his goal to empower him so as to channel some kind of vengeance: "I reveal myself in front of you so that you learn of my nature, so that the grandchildren of your grandchildren have some opportunity, an object for their fury" (p. 97 $)^{23}$. Even when on the brink of death, Gowan, personifying power, remains in control. At a more symbolic level, Gowan represents Europe and the capitalistic system, an elite with money and power that controls, manipulates and governs other less-empowered characters. The novel, thus, suggests a clear message when, at the end of the book, a bullet suddenly ends Gowan's life.

\section{Limbo, non-places and hybridity}

Gowan chooses Nabil, a choice that reflects his fascination with the desert, crisis and ruins. In Nabil's life, the desert is the past, his origins, while for Bruno Gowan "the desert is the future" ${ }_{24}$ (p. 98). If the desert is the past and the future, the present is the crisis and its ruins. When Lázaro, the man looking for Bruno Gowan, visits Gowan's house, he is led to a room in the basement where Gowan spent most of his time while at home. Everything in this room is white. Its emptiness is broken only by the presence of a table, a chair and a wall covered with photos depicting contemporary ruins, such as buildings fallen apart, stranded oil ships and abandoned planes. Etymologically, limbo comes from the notion of border, the border that can deny access to heaven or hell after death, usually to newborns and the unbaptized. Limbo is thus a space in-between - between life and death, between earth and heaven - and is a place for the unwanted, a place of uncertainty and oblivion. Ruins are limbic in the sense that they are a place of transition, a pause between prosperity and oblivion, a place of decay. The final stage of the ruination process would be a place where the stones have decomposed because of the wind and the rain, leaving only a desert behind, with its most basic element: the sand. In this sense, ruins are the limbo where, now dead and deprived of their function, these buildings are on a journey towards what Gowan

23 "Me desvelo ante ti para que aprendas mi naturaleza, para que los nietos de tus nietos tengan alguna posibilidad, un objeto para su furia” (p. 97).

${ }_{24}$ "el desierto es el futuro" (p. 98) 
sees as the future, the desert. The ruins portrayed in the text are of a special kind, one not so much linked to the effects of time, as in Roman ruins, but rather to the consequences of the crisis: buildings whose construction has not been completed because of the financial collapse and that now, unfinished, are crumbling into dust. Gowan is, however, not only a passive observer of ruins but also a creator of them. As Josefina tells Lázaro, guided by "a spirit both scientific and artistic" (p. I 85$)^{25}$, Gowan has in the past bought properties (a hotel, a restaurant) with no economic interest in them but instead with the aim of letting them decay. His neglectful acquisitions are an echo of the financial operations that caused the crisis, where toxic assets were bought and sold. Space becomes thus an object that can be bought, sold, and trashed, and comes to represent a wider economic reality where capitalism rules and where a large part of the population is ruined.

If Nabil's vital fight has been to move from the periphery to the center, Gowan's quest had been towards a limbo, represented by the desert and the ruins. At the same time, it is interesting to see the spaces in the novel that are linked to Gowan. Michelle Murray has mentioned the recurrence of non-places (20I6, p. 77), following Marc Augés definition, and Gowan is definitely associated with such spatial spheres. In two different chapters Gowan is seen in a hotel room and in another two, the action takes place during a taxi ride. At the end of the novel, he is murdered in a hotel's conference room. When still living at home, the place where he spent most of his time, the white room mentioned before, was deprived of all signs of homeliness or habitation. Michelle Murray discusses how the abandoned plane used as a shelter by the homeless is a non-place "reverted back into a place" (2016, p. 85). Gowan's room reverses that process when he makes the place of permanence par excellence, the home, a place commonly full of the traces of its inhabitants, a space that is empty and impersonal. When Lázaro visits Gowan's house, he expresses the impression that "Gowan had started to disappear from his own house a long time ago" (p. IOI $)^{26}$. Just as there is a subversive

25 "un espíritu al mismo tiempo científico y artístico" (p. I 85 ).

26 "Gowan había empezado a desaparecer de su propia casa desde hacía bastante tiempo" (p. IоI). 
element to the squatting of abandoned planes, Gowan's presence in different non-places runs parallel to his rebellious quest for change.

Another character who is repeatedly associated with nonplaces throughout the text is Jorge. Jorge lives in the plane with Nabil, works in a Chinese bazaar and appears at places of leisure, such as an ice-skating arena, Eurovegas or a hotel's conference room. Physically, Jorge is characterized by the fact he is overweight. Frequent allusions are made to his amorphous body and to a crust on his head, which he describes as his cradle cap and which everyone finds disgusting. On a psychological level, Jorge has Asperger's syndrome and his communication with other people is difficult. There are thus several borders, both physical and mental, that arise between him and the people around him and make him seem strange and abnormal, an Other in the text. Twice Jorge is seen talking to customers in the Chinese bazaar, and both times the customers leave suddenly after listening to his unconventional conversation full of complex logic and lacking the most basic social skills.

The non-places Jorge is associated with are characterized by their hybridity and, at the same time, by a sense of falseness. Teresa Gómez Trueba (2012, p. 59) writes about the relation between Marc Augé's non-place and Baudrillard's simulacrum. Although Augé's non-place and Baudrillard's simulacrum are in no way synonymous, in 2020 , Jorge is often found in spaces that combine both notions. Whereas Gómez Trueba calls the city of Las Vegas a "simulacrum paradigm" 27 (2012, p. 68), what can be found in 2020 is a simulacrum of a simulacrum, embodied by a place called Eurovegas, a recreation of Las Vegas in Madrid ${ }^{28}$. The narrator outlines the reasons why Jorge likes this place:

That is why he likes Eurovegas, because he does not need to worry about difference here. Everything here is fake. He knows what to expect. The brightness of the luxury cars, the contagious vitality

27 “paradigma del simulacro" (p. 68).

${ }_{28}$ Eurovegas was an idea to construct a gambling and leisure resort on the outskirts of Madrid conceived by Sheldon Adelson, an American business executive. In 2013 , after long negotiations with local authorities, the project was cancelled. 
of the neon lights, the bodies' eroticism. That is real. The real here is the surface, the makeup, the accidents, the attributes. Even he, so proud at other times, hides his crust under a cup that advertises Ron Havana. ${ }^{29}$ (p. 217)

Jorge's strategies to avoid his sense of exclusion are various and often linked to space. In the quote above, we can see that the falseness of Eurovegas allows him to transform, to hide under his cap and thus conceal a part of his difference. Just like Eurovegas, Jorge becomes a simulacrum of himself. Another place where he seems to fit in is his workplace, a Chinese bazaar in Madrid. In his portrayal of this place, Jorge seems to be conscious of his otherness:

I like it when an object serves a function that is not exactly suitable, like a bedroom carpet reused in the living room or a bathroom lamp hanging in the kitchen ceiling. An occidental working in a Chinese bazaar is a good example as well. The Chinese are the only ones who do not care about my crust. As long as you are happy with a crappy salary. The rest is none of their business. $(\text { p. } 34)^{30}$

The first sentence of this quote displays both hybridity and difference, a mixture of different functions and the transfer to new places. There are different aspects to this transfer. National identity could be one: people moving to a place where they do not belong and where they feel the otherness inherent in their "malplacement". In Jorge's thoughts, though, his difference and movement is not only national, from Spanish to Chinese; it has

29 Por eso le gusta Eurovegas, porque aquí no necesita preocuparse de la diferencia. Aquí todo es fingido. Sabe a lo que atenerse. El brillo de la carrocería de los coches de lujo, la vitalidad contagiosa de los neones, el erotismo de los cuerpos. Eso es verdadero. Lo verdadero es aquí la superficie, el maquillaje, los accidentes, los atributos. Incluso él, tan orgulloso de ella en otras circunstancias, oculta su costra bajo una gorra publicitaria de Ron Havana. (p. 217)

3o Me gusta cuando un objeto desempeña una función que no le corresponde exactamente, como una alfombra de dormitorio reciclada en alfombra de salón o una lámpara de baño colgando del techo de la cocina. Un occidental trabajando en una tienda de chinos también sirve como ejemplo. Son los únicos, los chinos, a los que no les importa lo de mi costra. Basta con que te conformes con un sueldo de mierda. Lo demás no les incumbe. (p. 34) 
a wider range. For when working in the bazaar he feels no need to hide and the disgust often projected towards him is replaced by indifference. In a homogeneous human landscape, Jorge sticks out and his otherness, both physical and psychological, produces aversion around him. Jorge's strategy to avoid rejection is thus to place himself in non-homogeneous spaces, in spaces of difference, hybridity and falseness, such as Eurovegas or the Chinese bazaar.

These non-places have a dual value. On the one hand, they are a refuge for Jorge. On the other hand, they exert and expose a precarious system. Jorge protects himself under the wings of hybrid fake places, but this same hybridity exposes him to a system of exploitation. His own precariousness, as he calls it, a "crappy salary", is an echo of a more widespread reality:

Chinese women can now be blond and Spanish. The crisis made the miracle. Millions and millions of Spanish converted into cheap labor. Chinese from El Ferrol, Chinese from Albacete, Chinese from Madrid. We do not need to bring immigrants here to do the dirty work anymore. Globalization has made them shelter in precarious work contracts. They hand out adverts for one of the casinos in the complex. They look happy and scared. (p. 2I 5$)^{31}$

National identity dissolves under the influence of globalizing capitalistic precariousness. Multiculturalism and hybridity are sarcastically used to denounce an economic system where exploitation becomes the norm. A few pages after this quote, precariousness takes on even darker tones with the allusion to a group of prostitutes waiting in the hotel conference hall. Jorge immediately falls for one of them, whom he believes to be of Slavic origin. In his thoughts, he imagines the girl as the result of a long history of events, including far away episodes such as the extinction of the dinosaurs as well as the violent rape of a peasant woman by a Napoleonic soldier. Hybridity and interculturality

${ }^{3}$ Ahora las chinas pueden ser rubias y españolas. La crisis obró el milagro. Millones y millones de españoles convertidos en mano de obra barata. Chinos de El Ferrol, chinos de Albacete, chinos madrileños. Ya no hace falta traer inmigrantes para que hagan el trabajo sucio. La globalización los llevó a refugiarse en brazos de contratos de trabajo precarios. Reparten publicidad de uno de los casinos que pueblan el complejo. Parecen felices y asustadas. (p. 2I 5 ) 
take on, in Jorge's thoughts, brutal and cosmic tones: "Her beauty redeems, on its own, all of the bloodshed in the past, the vastness and meaninglessness of a universe which has managed to produce that diamond" (p. 220) ${ }^{32}$. Although the violently described rape happens only in Jorge's mind, it illustrates a wider phenomenon in 2020: the connection of certain traditional postcolonial notions, such as the Other or hybridity, with not so positive concepts, with destruction, poverty, exploitation and undesirability. The portrait of Jorge is far from sympathetic. He remains a stranger to the reader, who shares the feeling of the teenager who comes into the shop where Jorge is working to buy some bullets and thinks that "There is something strange in the way that man speaks, as if he ignored his possible interlocutor" (p. 92) ${ }^{33}$. Throughout the text, there is a connection between Jorge and the space that contains him. In the first chapter of the novel he is seen at an iceskating arena where his amorphous and heavy body is contrasted with the lightness and agility of the female skater: "The skaters come from the cold. They turned and moved on the ice with the lightness of mythological beings... He raised an arm and felt gravity seizing it, a catenary of fat obeying an abstract mass situated in the center of the Earth" (p. II-I 2$)^{34}$. In the following chapters, Jorge moves in different hybrid spaces (the Chinese bazaar, the abandoned plane, Eurovegas) until the final chapter where we find him in an even more atypical scene - a hotel's conference room that is hosting performance art. There, on the stage, a group of cooks prepare pork-based dishes while, inside a small folk-like enclosure, a group of artists utter the different sounds from the lifecycle of a pig, including the sound of bacon being fried. Jorge walks into this space with a gun and shoots, killing Gowan and a woman. Gowan's murder is echoed in the space that contains him and that is stageing the lifecycle of a pig at the hands of the

32 "Su belleza redime por sí sola toda la sangre derramada en el pasado, la vastedad y el sinsentido de un universo que ha logrado producir ese diamante" (p. 220).

33 "Hay algo extraño en el modo de hablar de ese hombre, como si ignorara a su posible interlocutor" (p. 92)

34 "Las patinadoras venían del frío. Giraban y se desplazaban sobre el hielo con la levedad de seres mitológicos... Elevó un brazo y sintió la gravedad atenazándolo, una catenaria de grasa obediente a un centro de masas abstracto situado en el centro de la Tierra” (p. I I-I2). 
meat industry. It is relevant, though, that Jorge, while perpetrating this massacre and his subsequent suicide, is listening to a German heavy metal band through his earphones and is, thus, acoustically isolated from his surroundings. Jorge sings the text: "Ich will eure Stimmen hören. Ich will die Ruhe stören. Ich will dass ihr mich gut seht. Ich will dass ihr mich versteht" (p. 256)35. Jorge clings to his rifle and sings sadly, scared and angry at the same time. Jorge's final words are thus a desperate cry against his isolation, against his otherness, against the physical and psychological borders that keep him from being seen and understood.

\section{The Body as a Border}

2020 contains references to the bodies of most of its characters. In the case of Nabil, his body carries the ethnic features that mark his origin and his difference. Gowan, on the other hand, is described as muscular in what seems an echo of his overall superiority and his almost superhuman levels of performance. I have already mentioned how corporeality has an important role in Jorge's otherness. Jorge is repeatedly described as heavy and amorphous. The crust on his head creates repulsion and causes him to be rejected by the people around him, which only increases his sense of isolation. The character, however, whose body is mentioned most insistently is Josefina. From her first appearance in the text, the construction of her character is built upon repeated allusions to the beauty of her body, to the way she observes the reflection of her figure, to the way she moves, to the poses she strikes, to her anorexic traits. Josefina is obsessed with her body, as, seemingly, are the people around her. Josefina's body is described as extremely beautiful and at the same time as excessively thin due to her anorexia. As opposed to Jorge, whose body becomes an obstacle between himself and others, Josefina's body attracts other people. In a scene in an art gallery, Josefina stops to look at one of the pieces on display. Her mere presence in front of the installation has a magnetic effect and the gallery space, originally deserted,

35 The text is from the song "Ich Will” by the German group Rammstein, which can be translated to English as: "I want to hear your voices. I want to disturb your rest. I want you to see me well. I want you to understand me". 
soon fills with visitors. Not only does her physical presence attract other people to the spot, but her being there seems to increase the value of the installation: "You could say that it is Josefina's stunning presence that gives value to the work" (p. 32 $)^{36}$. However, in this scene and in others, Josefina is alone and isolated. In this respect, there is one element central to Josefina: the gaze, both that of others and her own. In a way, the gaze supposes an ephemeral crossing and at the same time it works as a confirmation of the border between bodies and of the distance and isolation between characters. In 2020, however, the gaze also serves as a means of communication, a means to break down the isolation and cross a border. To Josefina, the gaze is a form of contact, a soft "graze" ${ }_{37}$ (p. 229) and, during her walks in the center of Madrid, she has the habit of counting the number of looks that her body attracts. The connection between gaze and desire becomes patent in the scene where Josefina calculates the desire thrown at her during a day, eventually reaching a record two hundred and fifty-three looks which added together created a "memorable, kilometer-long orgasm" (p. 230 $)^{38}$. Josefina thus inverts the power relation implicit in the gaze, as Foucault proposes it ${ }^{39}$, by appropriating these looks for her own pleasure. She revolts against her role as an object by seizing the desire in the gazes of others and using it for her own gain. Another way Josefina takes power from other people's gazes is by looking at herself and thus becoming the subject. The first time the reader meets Josefina, she is in a shop:

Josefina enjoys looking at herself in the mirrors that cover the walls of the boutique. She places herself at the right distance. She knows that the optimum degree of beauty is a question of scale. Some people look attractive seen from a distance. Others reserve the best of their anatomies for the close-up. Josefina's figure requires three or four meters to deploy all of its seductive potential. She takes a bag from one of the counters, looks at herself and, in the image

36 "Puede decirse que es la presencia imponente de Josefina la que otorga valor a la obra” (p. 32).

37 “roce" (p. 229).

38 “orgasmo kilométrico y memorable" (p. 230).

39 In Discipline and Punish: the Birth of the Prison, Foucault writes about the role of the gaze as a means of power to enforce discipline and create "docile bodies" that are suitable for the modern age. 
thrown back by the mirror, she thinks about an advertising poster. More Coco Rocha than Zahia Dehar. (p. 27) 40 $^{\circ}$

This quote illustrates several phenomena that are associated with Josefina's body. The distance that separates her from others is patent in the three or four meters needed to best appreciate her beauty. Her contemplation of herself, far from being a natural action where she enjoys her own beauty, is described as being self-conscious with a hint of both surveillance and posing. Throughout the text, Josefina compares herself to different models and actresses and she seems to pursue an imitation of their beauty and glamor.

We have mentioned before the notion of simulacrum when studying Jorge's relation to space and his dwelling in locations such as Eurovegas. Similar parallels can be drawn in the character of Josefina between the imitation processes described before and some of the spaces she inhabits. The "Barrio de las letras", a quarter in the center of Madrid, is described as being renovated "the way many of Madrid's quarters are renovated, imitating some arrondissement in Paris" (p. 29) ${ }^{4 \mathrm{I}}$. This imitation echoes the repeated scenes where Josefina is seen mimicking a model's gestures or looks or walking with "her Loewe hanging from her arm with that gesture full of orthodoxy which consists in keeping the joint in a perfect ninety degree angle, as she had seen Audrey Hepburn do in Rome, or as the Japanese Lolitas do under a paradise of neon lights" (p. 29) $)^{42}$. Both Josefina and the space she moves in are thus

$4^{\circ}$ Josefina se recrea en los espejos que cubren las pareces de la boutique. Se coloca a la distancia adecuada. Sabe que el grado óptimo de belleza es un asunto de escala. Hay personas que resultan atractivas vistas de lejos. Otras reservan lo mejor de su anatomía al primer plano. La figura de Josefina requiere de tres o cuatro metros de distancia para desplegar todo su potencial de seducción. Toma un bolso de mano de uno de los mostradores, se mira y, en la imagen que le devuelve el espejo, contempla un cartel publicitario. Más Coco Rocha que Zahia Dehar. (p. 27)

${ }_{4 \mathrm{I}}$ " "de ese modo en que se rehabilitan los barrios de Madrid, imitando a algún arrondisement parisino" (p. 29).

42 "su Loewe colgado del brazo con ese gesto pleno de ortodoxia que consiste en mantener la articulación en un perfecto ángulo recto, como ha visto hacer a Audrey Hepburn en Roma, como hacen las lolitas japonesas bajo un paraíso de neones" (p. 29). 
imitations of something else, something supposedly sophisticated and lavish.

These processes of simulation point to a wider function of the body in 2020 , one related to a discourse on the existing socioeconomic system and the decay it implies. As mentioned previously, Murray sees the airplane used by the homeless as the representation of the economic crash and its consequences. In a similar way, Josefina's body can be seen as an element of a bigger economic system. Josefina's allusions to her body are accompanied by references to luxury items, to advertising and to statistics. She describes her eating disorder in economic terms:

Anorexia is an exhausting system of production. There is not a day goes by that I do not throw myself overtired on the sheets... I am open twenty-four hours a day, at full performance. My diet is made of flux and limitless availability. To reject food is work. To let parts of other bodies come into my body is work. Buying is an exhausting activity. My organism is a factory. My mind is the employer. I produce void nonstop, depriving the flesh. (p. I 33$)^{43}$

The metaphor of Josefina's body as a reflection of a mercantile system is very explicit. The final remark on void as the product of her extenuating efforts makes her anorexia a mirror of a capitalistic system engaged in the production of unnecessary items, of invented needs, of nothingness. There is a duality in Josefina's relationship to her body. In a sense, she has lost control and become a mirror of bigger external processes; she has become a reflection of an economic system that rules her as well as the rest of the characters. She is in that sense a slave to capitalism, a mode of production that leaves its traces on her body and her life. Even if, as the above quote suggests, to Josefina's mind she is "the employer" and is, therefore, in charge, the impression is that she has only a limited control over her body, that her body belongs to something

${ }_{43}$ La anorexia es un sistema de producción agotador. No hay día que no me arroje exhausta sobre las sábanas. ... Yo permanezco abierta veinticuatro horas al día, a pleno rendimiento. Mi régimen está hecho de flujo y disponibilidad sin límite. Rechazar la comida es trabajo. Dejar entrar en mi cuerpo a partes de otros cuerpos es trabajo. Comprar es una actividad extenuante. Mi organismo es una fábrica. Mi mente es el empresario. Produzco vacío sin descanso, despojamiento de la carne. (p. I33) 
beyond her, that it is part of a bigger system that governs all the characters. Josefina demonstrates a tenacious desire to control her body and still it seems not to belong to her. In the scene where Lázaro meets her for the first time: "[Josefina] approached me and feebly extended her hand to me, as if offering an object you are not too sure you possess" (p. IOO ${ }^{44}$. The duality and contradiction inherent in Josefina's relation to her body become even more patent when she speaks about her anorexia, in terms opposed to the ones quoted before, not as a mirror of the economic system but as a form of revolt:

Revolution is a product Josefina consumes now and then. Everyone is unhappy about something, everyone wishes for things to change. It is logical that we show our discontent with a t-shirt or a raised hand. You do not need to go further. After all, the enemy does not have a face, it is a monster that has mutated to become a part of ourselves. The only reasonable opportunity to unleash our rage is to infringe upon our own body or - as we all are guilty of doing to use indiscriminate violence. (p. 30$)^{45}$

These lines contain two kinds of revolt: a tame one embedded in the very system it wants to fight and a more personal and violent one. Josefina's anorexia has to be seen in the context of this "rage", that she, on the one hand, shares with her father. Just as Josefina's body is described as a production system, Gowan's DNA is "connected to that stock market code that only his body is able to metabolize and make into organs, moving muscles, into a human semblance capable of speech and extraordinarily complex thought" (p. II4 $)^{46}$. Both daughter and father are invaded

44 “[Josefina] Se acercó para tenderme lánguidamente la mano, como quien ofrece un objeto de cuya posesión no se está del todo seguro" (p. I००).

45 La revolución es un producto que Josefina consume de vez en cuando. Todo el mundo está descontento con algo, todo el mundo desea que cambien las cosas. Es lógico manifestar nuestro malestar con una camiseta o una mano alzada. No hace falta ir más lejos. Al fin y al cabo el enemigo carece de rostro, es un monstruo que ha mutado hasta convertirse en una parte de nosotros mismos. La única posibilidad razonable de dar rienda suelta a nuestra rabia consiste en atentar contra el propio cuerpo o - puesto que todos somos culpables- el uso de la violencia indiscriminada. (p. 30)

46 "conectado con ese código bursátil que solo su cuerpo es capaz de metabolizar para convertirlo en órganos y músculos en movimiento, en una 
by the enemy that "does not have a face" (p. 30), and both seem to engage in revolts of different characters, but which share their relation to the body, the gaze and the void. Whereas Josefina performs her revolt through and against her body, Gowan uses audiovisual practices. Part of his revolt involves the creation of a television channel called "channel I3", which broadcasts only "white noise", an image with hypnotic effects and clear connections to a void. Gowan's revolution is also observational, not only because watching channel I $3_{3}$ implies a gaze but also because he has set up a network of cameras that spy on and record the lives of certain individuals in high positions. The broadcasting of short bits of these recordings on his channel I 3 unites both void and gaze and the central role of this channel is suggested by Javier Moreno, the author, who appears as a character in the novel and reveals that the novel originated while he was watching channel I3. Both Josefina and Gowan thus produce void, Josefina through her body and Gowan via his channel I3. Both share the possession of a sick body: Josefina's sickness is her eating disorder and Gowan's is a kind of cancer or virus that seems to be taking over his body.

It is Jorge and Josefina's bodies, though, that have the greater presence in the text, especially since they are deviant in certain ways. Their bodies reveal opposed mechanisms, such as the duality of repulsion-attraction mentioned before. However, the contradiction between the two characters is wider than their opposition. Even at the heart of the description of Josefina's anorexia, one can see how the same body can be a servant for an economic system and a means of revolt, an object of gaze and power and an empowered gaze collector. Duality and contradiction are once again at the center of the text.

\section{Conclusions}

In the fourteenth chapter of this fragmented novel, the narrating voice reflects on notions of otherness, identity and assimilation. Moreno states that only a very small part of the population can escape what he calls "mimetic crisis", a crisis based on the dual wish to maintain a personal identity and at the same time be part

apariencia humana capaz de habla y pensamiento extraordinariamente complejo" (p. II4). 
of a bigger reality. The few that are devoid of these worries are what the narrator describes as a powerful predatory elite, once again raising a border between them and the rest of the characters, maintaining their inaccessibility to the point that they remain completely unknown to the rest. This reading of 2020 has shown how the novel is articulated around a series of characters whose otherness adopts different expressions, including the migrant, the sick, the diagnosed, the anorexic or the homeless. Nabil, whose status as both migrant and homeless person makes him the archetypal Other, is aware of the fact that he never had anything. This differentiates him from the majority of people affected by the financial crisis, the "disinherited" people who have lost something because they had something, or at least the promise of something. Nabil, uninherited instead of disinherited, is a border-crosser who tries to move towards the center, although his steps seem to take him to different peripheral locations, as if he was climbing an escalator that was going down, taking him from the desert to the outskirts of Madrid and finally to a remote part of a busy airport. On a deserted landing strip, he lodges in an abandoned plane, an echo of a bigger crisis but also of a character fighting to find a place and a function in society. If Nabil is trying to move towards the center, Gowan, a character whose otherness is based on his prodigious superiority, is travelling in the opposite direction, as he moves from a central position of power to a peripheral one from which he seeks to revolt. We have seen how the occupation of the plane by the homeless inverts Augés notion of non-places, by turning the transitory into the permanent. Gowan's special room in the cellar seems to do the opposite: in the heart of the permanent, of the home, Gowan creates impermanence, a white room, blindingly bright and seemingly temporary. This room underlines Gowan's obsession with the desert and with ruins, to the point that he becomes not only an observer of ruins but also their creator. Buying properties with the intention of letting them turn to ruin, Gowan's actions represent a wider economic reality where objects can be bought, sold and trashed.

Two key characters in the novel are Josefina and Jorge. Both are characterized by their bodies, which act as borders that isolate them in very different ways. A key notion in this study of Jorge has been hybridity, for it is in hybrid spaces, such as the Chinese bazaar, where his difference becomes diluted, but he is exposed to 
a system of exploitation. Simulacrum has also been an important idea, embodied by Eurovegas, a place where Jorge can be found masking his difference. Josefina and her body have also been associated to simulacrum as she relentlessly seems to imitate the beauty found in fashion magazines and the media. Her simulation, and the anorexia attached to it, mirrors a wider socioeconomic system, a void-producing and enslaving process. In both Josefina and Gowan, as well as in the other characters examined here, body and power, gaze and desire, space and otherness, are key elements in the composition of a text that talks about difference in the context of a future society in crisis. Even if the dystopic vision of 2020 is far from apocalyptic, the whole novel has a sinister tone and through its portrayal of isolated and deviant characters and spaces, it builds a world in ruins that leaves little to hope for.

\section{References}

Anzaldúa, G. (I987). Borderlands: The New Mestiza. La Frontera. San Francisco: Aunt Lute.

Augé, M. (1995). Non-places: introduction to an anthropology of supermodernity. London: Verso.

Baudrillard, J. (1994). Simulacra and simulation. Ann Arbor: University of Michigan Press.

Becerra, D. (ed.) (2015). Convocando al fantasma. Novela crítica en la España Actual. Madrid: Tierradenadie.

Celaya-Carrillo, B. (20I I). "Pánicos racistas: reflexiones sobre la inmigración en Cataluña y España a partir de un texto de Najat El Hachmi," MLN, I 26(2), pp. 344-365.

Chirbes, R. (2013). En la orilla. Barcelona: Anagrama.

Foucault, M. (I99I). Discipline and punish: the birth of the prison. Harmondsworth: Penguin.

Gómez Trueba, T. (2012). "Nuevos espacios míticos para la última narrativa mutante: el no lugar y la estética del simulacro," Revista de Alces XXI. Journal of contemporary Spanish Literature \& Film. o, pp. 54-85.

Harvey, D. (2012). Rebel Cities. New York: Verso. 
Kamen, Henry (2007). The Disinherited: Exile and the Making of Spanish Culture, I492-1975. London: Allen Lane

Marín, M. (20I6). "Lisa McInerney: «La clase trabajadora ha sido olvidada en literatura»," El país. Available at: http://cultura.elpais .com/cultura/20 I 6/I 2/2 I/actualidad/I $482342980 \_099633 . \mathrm{html}$, (Accessed: Io September 2017).

McClung, W. A, (1988). "Dialectics of Literary Cities." Journal of Architectural Education, 4I(3), pp 33-37.

Mora, V. L. (20I4). "Welcome to Limbo: literatura hispánica entre lugares," Diálogos Latinoamericanos, 23, pp. 6-24.

Moreno, J. (2013). 2020. Madrid: Lengua de trapo.

Murray, M. (2016). "Capital Ruptures: Economies of Crisis and Urban Space in Javier Moreno's 2020," 452 F: Revista de Teoría de la Literatura y Literatura Comparada, I 5, pp. 7 I-92.

Rodríguez Marcos, Javier (2013). "Una crisis de novela," El País, Available at: https://elpais.com/sociedad/2013/03/I6/actualidad /I363470608_I3005I.html, (Accessed: Io September 20I7).

Valdivia, P. (2016). "Narrando la crisis financiera de 2008 y sus repercusiones," $452^{\circ} \mathrm{F}$ : Revista de Teoría de la Literatura y Literatura Comparada, I 5, pp. I 8-36.

Van Gennep, A. (I977). The rites of passage. London: Routledge \& Kegan Paul.

Vélez Sainz, J. (20I4). "La novela de la crisis," Huffington Post, Available at: http://www.huffingtonpost.es/julio-velez-sainz/la -novela-de-la-crisis_b_5309345.html, (Accessed: Io September 2017). 